\title{
Third generation universities: foreign experience and Russian practices
}

\author{
Anatoly S. Kislyakov ${ }^{1 *}$ and Tamara G. Chachua ${ }^{2}$ \\ ${ }^{1}$ Financial University under the Government of the Russian Federation, Department of Humanities, \\ Moscow, Russia \\ ${ }^{2}$ Financial University under the Government of the Russian Federation, Faculty of Social Sciences \\ and Mass Communication, Moscow, Russia
}

\begin{abstract}
The article analyzes the third generation universities and their main features according to the methodology developed by Johan Wissema. The world experience in building third generation universities can be based, according to the authors, on the three main models described in the present study, namely, the models used by Harvard, Cambridge, and the University of Ruse. The main purpose of the present study is to analyze the main advantages of third generation universities on the example of international and Russian practices. The universities, selected as research objects, not only show high results in international rankings and the scientific community but also have strategic importance for the development of their regions. However, the most important criterion remains the commercialization of know-how and the active involvement of the educational organization in the regional economy, which is demonstrated by all three universities selected for the analysis of global practices. Each of the presented models has its peculiar characteristics and can be adapted for forming the Financial University under the Government of the Russian Federation (Financial University) into a new third generation university that can be created taking into account the capabilities and available facilities and resources, as well as the scientific and educational-methodological base.
\end{abstract}

Keywords: modernization of the education system, transformation of universities, know-how, research activities.

\section{Introduction}

In the modern world, the education system is undergoing enormous changes due to the development of digital technologies, globalization, and the fourth industrial revolution. Respectively, the labor market is also changing (for example, skills, such as digital literacy, programming, and working with a large amount of data are becoming more demanded). Changes in the economy and society give impetus to changes in higher education not only in Russia but also around the world. The most important thing that the education system retains is the opportunity for a person to become competitive, to be able to use the knowledge and skills acquired at universities. However, the contemporary education system

* Corresponding author: askislyakov@,fa.ru 
also has several features that distinguish it from the previous ones - today universities should become catalysts for the development of an innovative economy [1].

The present study pursues the following objectives:

1. Formulating the main distinctive elements of third generation universities.

2. Analyzing the global practices of building third generation universities.

3. Analyzing the development of the Financial University in terms of implementing the main elements of the third generation university.

Solving set tasks will allow justifying the importance of modernizing contemporary universities and possible benefits not only for students but also for the country's economy.

\section{Methods}

The object of the present study is the third generation university models implemented by Harvard, Cambridge, and the University of Ruse. In the course of the conducted research, the authors used methods, such as description (in particular, three development models of the third generation universities were described), comparison (a comparative analysis of the advantages and disadvantages of each of these models was carried out), and methods of historical analysis (three transformation and development stages of universities over time were considered).

\section{Results}

According to the model of Johan Wissema, which is outlined in his work "Towards the Third Generation University", the author distinguishes three stages in university development [2: 43-78].

The first generation universities (a medieval university whose concept was popular from about 1100 to 1700 ) originated from Latin schools and had just a single purpose - to transfer the knowledge accumulated in previous times. Second generation universities appeared in the middle of the 18th century, and besides transferring knowledge were engaged in research, i.e., in producing new knowledge.

Third generation universities have added a third task to the previously existing ones commercializing knowledge. They are distinguished by seven features [2]:

1. Extracting financial benefits from know-how.

2. Fighting for increased financial opportunities and the best specialists and students.

3. Becoming network organizations cooperating not only with the state but also with business and other structures.

4. Conducting interdisciplinary scientific research.

5. Relying on multiculturalism and a system of equal opportunities ${ }^{\dagger}$.

6. Acquiring cosmopolitan nature which is also a unique feature of third generation universities. Teaching students mainly in English

7. Moving out of the sphere of the state influence caused by the acquisition of certain financial independence from the state.

Within the framework of this study, three development models of the third generation universities were analyzed. The first model is presented by the Harvard University (USA), which year over year takes the leading places in the QS World University Rankings [4].

\footnotetext{
This principle allows creating special conditions for the scientific staff of the university, while, at the same time, successfully implementing programs of mass higher education.

FFor the prospects of using the Russian language in teaching, see the study of N.A. Orekhovskaya, E.I. Zamaraeva, E.V. Shikh, A.A. Galushkin, R.I. Platonova, A.M. Ishmuradova [3]
} 
Harvard is an example of how it is possible to combine elements of mass education, scientific component, and economic cooperation with private institutions in a single university.

One of the main features of third generation universities is their exposure to globalization, which is expressed in the fact that the university opens its doors to a large number of foreigners. Thus, about 22,000 students from 80 countries of the world study at Harvard. Of the total number, approximately $12 \%$ are foreign students [5]. Besides, Harvard is focused on active cooperation with other universities and business structures. Harvard, along with the MIT Sloan School of Management and the Center for Medical Technology, has launched a two-year MBA program for biomedical companies. The program trains specialists for 150 companies, which is an example of how universities can interact with private entities in different industries through the commercialization of knowhow $^{\S}[2]$.

Transdisciplinary research in third generation universities is perceived as a necessary condition for the development of science, but to conduct such research, the university must broaden its educational and scientific areas. Thus, Harvard incorporates a fair number of scientific schools that deal with design and health, law, and exact sciences. It is also worth noting that Harvard is not financially dependent on the state. As of June 2020, total operating revenue amounted to USD 5.4 billion. Harvard's revenues depend on three main sources, namely, education or training, sponsored research, and donations. Table 1 shows Harvard's revenue sources in 2020 [6].

Table 1. Harvard's revenue sources in 2020 .

\begin{tabular}{|c|c|}
\hline Type of source & Income ratio, $\%$ \\
\hline Endowment income & $37 \%$ \\
\hline Education or training & $17 \%$ \\
\hline Sponsored studies & $17 \%$ \\
\hline Donations & $9 \%$ \\
\hline Other & $20 \%$ \\
\hline
\end{tabular}

The university created a special endowment for donations (Harvard's Endowment), contributions to which allowed implementing leading programs, making groundbreaking discoveries in scientific research, and attracting hundreds of professors in a wide range of academic fields. In the fiscal year 2020, the foundation distributed USD 2 billion to various university structures. It can be concluded that such funds can become an important source of funding for third generation universities that will allow the university to develop dynamically based on public support.

One of the options for forming and developing a third generation university can be the example of the Angel Kanchev University of Ruse. This university with a 75-year history is one of the leading universities in Bulgaria. During the transition from a planned economy to

\footnotetext{
\$"Know-how carousel" (or "know-how hub") is a term describing the process whereby third generation universities take the initiative to become a hub that brings together various organizations involved in the creation and commercialization of know-how. Sometimes such a center can gain international recognition as a flagship in the creation of knowledge in specific scientific fields.
} 
a market economy, the university went through harsh times (lack of funding, suspension of research work), but now it has become one of the best universities in Bulgaria. The university also actively cooperates with other universities in Western countries, in particular, within the framework of the EU's Erasmus integration program. Table 2 shows that the university actively joins the international student community, and thus fulfills one of the important conditions for third generation universities - globalization and the struggle for the best students [1].

Table 2. Number of student and teaching staff participating in the Erasmus integration program.

\begin{tabular}{|c|c|c|c|c|}
\hline $\begin{array}{c}\text { Academic } \\
\text { year }\end{array}$ & $\begin{array}{c}\text { Exchange students } \\
\text { who left to study } \\
\text { abroad }\end{array}$ & $\begin{array}{c}\text { Students who } \\
\text { left for practice }\end{array}$ & $\begin{array}{c}\text { Teachers who } \\
\text { left for } \\
\text { training }\end{array}$ & $\begin{array}{c}\text { Foreign } \\
\text { students }\end{array}$ \\
\hline $2014-2015$ & 50 & 21 & 56 & 30 \\
\hline $2015-2016$ & 47 & 39 & 81 & 24 \\
\hline $2016-2017$ & 49 & 24 & 64 & 41 \\
\hline $2017-2018$ & 41 & 48 & 86 & 39 \\
\hline $2018-2019$ & 36 & 53 & 118 & 112 \\
\hline
\end{tabular}

The University also has its peculiar specialized centers and many departments, which allows it to focus on multiculturalism and be bidirectional, which is also a prerequisite for forming a third generation university. The management structure at the University of Ruse resembles Russian universities, in particular, the Financial University. Each faculty is headed by a dean, who reports to the university rector. The vice-rectors in the various areas are accountable to the rector. The University has more than 800 employees, while training is conducted by almost 500 highly qualified university teachers $[2,7]$.

The third model is based on the best practices of one of the oldest universities in Western Europe - Cambridge University (UK), which was founded in the 10th century and began to form as a third generation university since the 60 s of the last century when a significant number of high-tech companies appeared in Cambridgeshire. The interaction of the companies with the university resulted in the fact that the educational institution underwent a forced modernization and is now known as the Cambridge Phenomenon. After the end of the Second World War, firms actively began to create innovations in the field of electronics [8]. Cambridge was then a rural backwater, but even by the 1970 s, there were at least 20 companies in the area, while in 1987, the number of emerged companies exceeded 360. As a result, Cambridge has become a network organization that actively cooperates with business structures to commercialize the knowledge gained, and to ensure that the university is perceived not only as an educational institution but also as a center of attraction for new business connections and interactions with entrepreneurs. Exactly such a system is called the ecosystem of innovation and entrepreneurship.

The experience of Cambridge shows that the bet on the development of relations with private companies is justified since today the Cambridge Technopole has about 3,000 hightech enterprises which created about 60,000 new jobs [1,2]. Although Cambridge took an active institutional part in the activities of only $10 \%$ of firms, the idea of entrepreneurship had found great support among students and became the basis for the creation of the Cambridge University Entrepreneurs (CUE), which was able to gather talented and motivated students [9]. 
Summarizing the conducted analysis of the modernization of the University of Cambridge as a third generation university, it should be noted that the progress that has been achieved by this education institution resulted from a bold new policy for universities of this time, as well as from long-lasting reforms initiated in the $60 \mathrm{~s}$ of the last century. The modernization of the university began with the fact that the management realized that traditional sources of funding did not allow maintaining the leading position of the university.

Johan Wissema, speaking at Moscow State Institute of International Relations (MGIMO), noted that teaching activity was also on the way to change. Wissema also notes that today the status of teaching is subject to revision, and activity of a teacher becomes an independent profession. Changes are also taking place in the very educational process because the role of independent work of students is increasing, as well as educational platforms are developed [10], whose demand has especially increased in the context of the COVID-19 pandemic [11]. The Russian system of higher education does not stand still, and universities are ready to develop based on modern trends. For example, the role of information technologies in the educational process is increasing, open online courses are being popularized on Russian platforms, and pedagogical approaches are being improved [12].

\section{Discussion}

The Financial University has a century-old history. The University has come a long way from a small Moscow Financial and Economic Institute to one of the leading universities in the country. Certainly, some distinctive elements of third generation universities are peculiar to many Russian universities, as well as to the Financial University, in particular. For example, the total number of students enrolled in the main educational programs at the beginning of the $2020 / 2021$ academic year was 45,666 people, which proves the fact that the university is massive. At the same time, the Financial University has a large number of specialists engaged in the research area. The total amount of funds raised to finance research and development, and provide services in the scientific field amounted to RUB 422.9 million at the end of 2018 [13].

Also, the Financial University is increasingly becoming a network organization and pays great attention to cooperation with both government agencies** and business structures $^{\dagger}[14]$. Besides, the Financial University became the first Russian university to create an endowment fund, whose purpose was to form and replenish the endowment capital and distribute income in favor of the University. At the moment, the foundation is among the top 10 largest Russian university endowment funds in terms of accumulated means [15].

Today, the University is actively developing, implementing more and more new technologies for teaching students and university staff. The Financial University Development Program until 2030 includes several indicators that are typical for third generation universities. Thus, the strategic goal of the Financial University is to establish the educational institution as a multidisciplinary educational and scientific innovation center that could ensure the digital transformation of priority sectors of the economy and

\footnotetext{
** The main customers of the academic research works of the Financial University are the Executive Office of the Government of the Russian Federation, the Directorate of the President of the Russian Federation, the Ministry of Economic Development of the Russian Federation, the Ministry of Industry and Trade of the Russian Federation, and other state authorities.

$\dagger$ Business partners are organizations, such as JSC Rosselkhozbank, Gazprom, Rosatom, PJSC Sberbank of Russia, and several others.
} 
participate in ensuring the national security of the country. That is, the main activity of the University will include two key components: first, active involvement in scientific research, and secondly, the goal to become a center of the entrepreneurial type, and ensure the competitive development of national economic sectors.

The Development Program will be implemented in two stages [16]:

- At the first stage (2021-2024), a comprehensive ecosystem will be created, which will be able to provide competitive educational, innovative, and scientific activities for the development of human capital.

- At the second stage (2025-2030), the University will be positioned in the Russian and international community through the collaboration of education and science by creating a belt of consortia with business structures, scientific and educational organizations, and other enterprises for the promotion and subsequent commercialization of research and development.

Thus, it should be noted that the Financial University successfully adopts the best practices of the world's leading universities, and implements them in the educational process, which allows keeping up with changes in the education system, and remaining a place for forming personnel for the domestic economy and other areas of the state.

\section{Conclusion}

Summing up the research, it is worth noting that in the context of the fourth industrial revolution and globalization, universities were faced with two main challenges: an innovative challenge and an economic challenge. Each challenge can become a driver for the development of not only the education system but also national economies [17]. It is also worth noting that Russian universities face a difficult task: it is necessary to choose whether any of the third generation university models is suitable for them, or whether they should work out their peculiar development strategy.

The three development models of third generation universities can provide opportunities for finding a middle way for the development of domestic universities. Thus, the Cambridge University model is based on 40 years of experience in the development and commercialization of know-how through close collaboration with companies that were at that time also looking for development opportunities. The Harvard practices show how the university can benefit financially from know-how through multidisciplinary research and nongovernmental investment. The development path of the University of Ruse shows the opportunity for penetrating the economic processes of the region and using the investments of Western countries.

The development path of the Financial University is somewhat different. The age-long history of the University and its image in the higher education system provide an opportunity for accelerated modernization and closer work with both public and private agencies, whose main goal is the university's contribution to the domestic economy.

\section{References}

1. A.S. Kisliakov, A.D. Ishchenko, Vlast, 6, 196-201 (2019)

2. J. Wissema, Towards the third generation university: managing the university in transition (Edward Elgar Publishing, Northampton, 2009)

3. N.A. Orekhovskaya, E.I. Zamaraeva, E.V. Shikh, A.A. Galushkin, R.I. Platonova, and A.M. Ishmuradova, XLinguae, 12(4), 155-164 (2019).

https://doi.org/10.18355/XL.2019.12.04.13 
4. QS World University Rankings (n.d.). Accessed on: November 01, 2020. [Online]. Available: https://www.educationindex.ru/articles/university-rankings/qs/

5. Harvard College, Admissions Statistics (n.d.). Accessed on: November 01, 2020. [Online]. Available: https://college.harvard.edu/admissions/admissions-statistics

6. Harvard University, Financial Overview (n.d.). Accessed on: November 01, 2020. [Online]. Available: https://finance.harvard.edu/financial-overview

7. University of Ruse, Erasmus (n.d.) Accessed on: November 03, 2020. [Online]. Available: http://erasmus.uni-ruse.bg/bg/?cmd=cmsPage\&pid=17

8. T.K. Chernysheva, Nauchnyye Zapiski Molodykh Issledovateley, 6, 39-46 (2018)

9. University of Cambridge, Structure of the University of Cambridge (n.d.). Accessed on: November 04, 2020. [Online]. Available: https://www.cam.ac.uk/about-theuniversity/how-the-university-and-colleges-work/structure

10. E.V. Voevoda et al., Vysshee Obrazovanie v Rossii, 27(5), 59-73 (2018)

11. O.V. Mikhailov, Y.V. Denisova, Vysshee Obrazovanie v Rossii, 29(10), 65-76 (2020). https://doi.org/10.31992/0869-3617-2020-29-10-65-76

12. E.A. Romanova, The Moscow University Bulletin, Series 20, Pedagogical Education, 2, 54-59 (2018)

13. Financial University, Homepage (n.d.). Accessed on: November 05, 2020. [Online]. Available: http://www.fa.ru/univer/Pages/Home.aspx

14. Financial University, Partners (n.d.). Accessed on: November 05, 2020. [Online]. Available: http://www.fa.ru/partner/pcg/Pages/partners.aspx

15. Financial University, Ob endaument-fonde Finansovogo universiteta [About Endowment Fund of the Financial University] (2017). Accessed on: November 13, 2020. [Online]. Available:

http://www.fa.ru/science/endowment_fund/Pages/Home.aspx

16. Financial University, Programma razvitiya Finansovogo universiteta do 2030 goda [Development Program of the Financial University until 2030] (2020). Accessed on: November 05, 2020. [Online]. Available: http://www.fa.ru/univer/Pages/2030.aspx

17. M.D. Shchelkunov, Vestnik Ekonomiki, Prava I Sotsiologii, 1, 187-192 (2017)

18. K. Percy, "An alternative ageing experience”: an account and assessment of the university of the third age in the United Kingdom, in M. Formosa (Ed.), The university of the third age and active ageing. European and Asian-Pacific perspectives, 33-43 (Springer, Cham, 2019). https://doi.org/10.1007/978-3-030-21515-6_3

19. R. Patterson, S. Moffatt, M. Smith, J. Scott, C. Mcloughlin, J. Bell, Ageing and Society, 36(8), 1580-1603 (2016). https://doi.org/10.1017/S0144686X15000550 